\title{
Intestinal transcriptional profiling reveals fava bean-induced immune response in DBA/1 mice
}

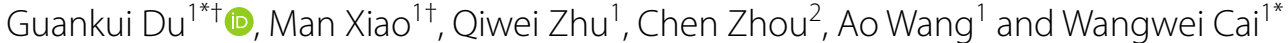

\begin{abstract}
Background: Fava beans (FBs) have long been used as food, and their principal disadvantage is derived from their haemotoxicity. We hypothesized that FB ingestion alters the intestinal gene expression pattern, thereby inducing an immune response.

Results: In-depth sequence analysis identified 769 differentially expressed genes (DEGs) associated with the intestine in FB-treated DBA/1 mouse intestines. The identified genes were shown to be associated with biological processes (such as response to stimulus and immune system processes), human disease pathways (such as infectious diseases, endocrine and metabolic diseases, and immune diseases), and organismal system pathways (such as the digestive system, endocrine system, environmental adaptation, and immune system). Moreover, plasma total immunoglobulin $\mathrm{E}(\mathrm{IgE})$, histamine, interleukin (IL)-4 and IL-13 levels were significantly increased when the mice were treated with FBs.
\end{abstract}

Conclusions: These results demonstrated that FBs affect the intestinal immune response and lgE and cytokine secretion in DBA/1 mice.

Keywords: Fava beans, Differentially expressed genes, DEGs, Immune response, Total IgE, Histamine

\section{Background}

Fava bean (FB) have long been used as food and feed because of their rich source of proteins and energy [1, 2]. Therefore, FB is prevalent in many areas, such as the Middle East and South America [1]. However, the main disadvantage of FB is derived from its haemotoxicity, which can induce favism in individuals with glucose 6-phosphate dehydrogenase (G6PD) deficiency [3].

Favism is an acute haemolytic disease that occurs 24-48 h after FB ingestion [4]. Favism occurs more frequently in 1- to 5-year-old children, and it is rare in adults. Several hypotheses have been proposed for the onset of favism, such as oxidized substances in FBs (such as divicine and isouramil), hereditary factors, and immunological factors [5-7]. Although all patients with favism

\footnotetext{
*Correspondence: duguankui@163.com; caiww591020@163.com

${ }^{\dagger}$ Guankui Du and Man Xiao contributed equally to this work

${ }^{1}$ Department of Biochemistry and Molecular Biology, Hainan Medical

College, Haikou 571199, China

Full list of author information is available at the end of the article
}

are G6PD-deficient, many patients with G6PD deficiency can ingest FBs without clinical symptoms [4]. Therefore, factors other than G6PD deficiency require further study.

Food allergies are a severe health problem in approximately $6 \%$ of infants younger than 3 years [8]. Immunoglobulin E (IgE) mediates acute allergic reactions, such as urticaria, vomiting, wheezing and anaphylaxis, that manifest after the ingestion of food $[9,10]$. After allergic sensitization has occurred, $\mathrm{CD} 4{ }^{+} \mathrm{TH} 2$ cells secrete antiinflammatory molecules [interleukin (IL)-4 and IL-13], which result in the overproduction of IgE $[11,12]$. IgE binds the high-affinity IgE receptor FceRI on the surface of mast cells $[13,14]$. Subsequently, the mast cells rapidly release proinflammatory mediators (such as histamine), which induce the acute phase of the allergic response [15].

Notably, a few case reports have shown allergic reactions to FB [16]. Damiani et al. [17] showed occupational allergies induced by volatile substances released from FB. Moreover, Bousfiha and Aarab [18] showed that a high 
proportion of the Moroccan population has positive values for the IgE specific to the FB protein. Recently, Kumar et al. showed that mice have a severe allergic response to $\mathrm{FB}$, and undigested $\mathrm{FB}$ proteins may be the allergen related to allergic responses in mice and humans. It has been reported that the mucosal immune system in the intestine plays an important role in food allergies $[19,20]$. Therefore, we hypothesized that FB affects the expression of genes involved in the immune response in the intestinal tract to trigger allergic reactions. This study aimed to determine the gene expression profile of the intestine in $\mathrm{DBA} / 1$ mice after FB ingestion.

\section{Methods}

\section{Animals and treatment}

Animals were treated as approved by the Hainan Medical College Animal Research Committee. A total of 16 3- to 4-week-old male DBA/1 mice were obtained from the Model Animal Research Center of Nanjing University (Nanjing, China). All mice were housed in a room with a controlled environment (a temperature of $22 \pm 1{ }^{\circ} \mathrm{C}$, relative humidity of $50 \pm 5 \%$, and a 12 -h light/12-h dark cycle). Food and water were provided ad libitum. The mice were randomized into a control group and an FBtreated group ( $\mathrm{n}=8$ mice per group). As conducted in our previous study, the FB-treated mice underwent intragastric administration of $10 \mathrm{~g} / \mathrm{kg}$ body weight cooked FB homogenate $(20 \% \mathrm{w} / \mathrm{v})$, which could significantly induce oxidative stress [21], and the control mice underwent intragastric administration of the same volume of water. After $8 \mathrm{~h}$, blood samples were obtained from the ocular vein for analysis of the content of IgE, histamine, IL-1, and IL-13. The mice were sacrificed under chloral hydrate anaesthesia. Approximately $100 \mathrm{mg}$ intestinal samples, obtained $1 \mathrm{~cm}$ below the stomach, were sliced and frozen for deep sequencing analysis and reverse transcription PCR (RT-PCR).

\section{Biochemical assay}

The contents of plasma IgE, histamine, IL-1, and IL-13 were determined by ELISA assays using commercial kits (Elabscience Biotechnology Co., Ltd., Wuhan, China; IgE (E-EL-M0691c), histamine (E-EL-0032c), IL-4 (E-ELM0043c), and IL-13 (E-EL-M0727c)) according to the manufacturer's instructions.

\section{RNA isolation}

Total RNA was isolated by a TRIzol kit (Invitrogen, NY, USA) according to the manufacturer's instructions. Then, the total RNA samples from each group were further extracted in triplicate by an Oligotex mRNA Mini Kit (Qiagen, Valencia, CA) for RNA-Seq.

\section{RNA-Seq}

A BGISEQ-500 system (BGI, Shenzhen, China) was used for library construction and sequencing. The reads were matched with the reference genome of $M$. musculus (GRCm38 version 74.38; ensemble.org/Mus_musculus) by hierarchical indexing for spliced alignment of transcripts (HISAT) [22]. RESM software was used for gene expression analysis [23]. The differential expression of genes was isolated by a significance threshold (absolute value of a $\log 2$ ratio $\geq 1$ and an FDR $<0.001$ ).

\section{Gene ontology (GO) and pathway enrichment analysis}

DAVID software (http://david.abcc.ncifcrf.gov/) was used for gene ontology (GO) and kyoto encyclopedia of genes and genomes (KEGG) analysis [24, 25]. The enriched pathway was selected by the hypergeometric test with the Bonferroni correction.

\section{Analysis of mRNA expression by RT-PCR}

The sequence data were validated by RT-PCR. A total of $2 \mu \mathrm{g}$ of RNA was used to synthetize the first strand by a reverse transcription system (Promega, Wisconsin, USA) according to the manufacturer's protocol. The PCR reactions $(20 \mu \mathrm{L})$ contained $20 \mathrm{ng}$ of template cDNA, $10 \mu \mathrm{L} 2 \times$ Master Mix (Sigma-Aldrich, Dorset, England), and $10 \mu \mathrm{M}$ of each forward and reverse primer (Additional file 1: Table S1) (Sangon, Shanghai, China).

\section{Statistical analysis}

All data are presented as the mean \pm standard error (SE). Significant differences among the groups were analysed using Student's t-test. A P-value $<0.05$ was considered statistically significant. All analyses were performed using GraphPad Prism version 5.0 (GraphPad Software, San Diego, CA).

\section{Results}

Differentially expressed intestinal genes after FB ingestion Based on strict statistical criteria (median FDR $<0.01$; fold change $>2$ ), SAM analysis identified 769 differentially expressed genes (DEGs) of the intestine between the control and FB-treated groups (Fig. 1). Of these genes, 629 were significantly upregulated, and 140 were significantly downregulated (Additional file 2: Table S2).

\section{Gene ontology (GO) analysis of DEGs}

To obtain insights into the functions of the identified DEGs, gene ontology (GO) analysis was performed (Fig. 2). These genes were shown to be mainly involved in the following biological process categories: 


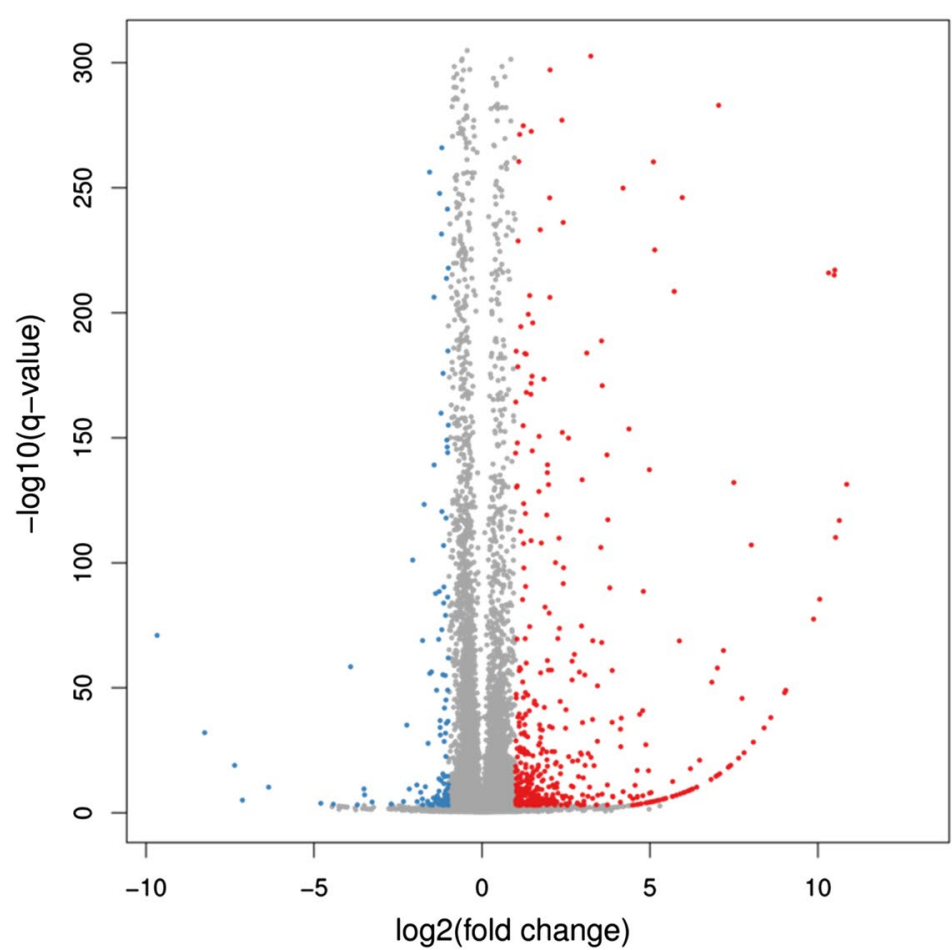

- Up: 629

FoldChange $\geq 2$, qValue $\leq 0.001$

- Down: 140

FoldChange $\leq-2, q$ Value $\leq 0.001$

- no-DEGs: 17842

abs (FoldChange $)<2$ or qValue $>0.001$ fold change. The Y-axis represents the $-\log 10$ transformed significance. The red points represent upregulated DEGs. The blue points represent downregulated DEGs. They grey points represent non-DEGs

response to the stimulus, biological regulation, multicellular organismal process, localization, developmental process, regulation of biological process and immune system process. These genes were shown to be mainly involved in the following molecular function categories: binding, catalytic activity, transporter activity, molecular transducer activity, signal transducer activity, molecular function regulator, transcription regulator activity, structural molecule activity, and antioxidant activity. Additional file 3: Table S3 lists the differentially expressed genes implicated in each of the functions mentioned above.

\section{Pathway analysis of differentially expressed genes}

We performed KEGG pathway classification and functional enrichment of the DEGs. As shown in Fig. 3 and Additional file 4: Table S4, the DEGs were associated with 6 branches for KEGG pathways: cellular processes, environmental information processing, genetic information processing, human disease (for animals only), metabolism, organismal systems and drug development. Notably, DEGs associated with human diseaserelated categories are as follows: infectious diseases: viral, endocrine and metabolic diseases, cardiovascular diseases, infectious diseases: bacterial, infectious diseases: parasitic, neurodegenerative diseases, and immune diseases. Furthermore, DEGs associated with organismal system-related categories are as follows: digestive system, ageing, circulatory system, development, endocrine system, environmental adaptation, excretory system, immune system, nervous system, and sensory system.

\section{RT-PCR verification of the sequencing results}

For validation of the sequencing data, a group of genes known to be directly or indirectly implicated in the immune response was used for RT-PCR. These genes included Tlr2, Tlr4, Map3k7, Foxp3, Nox1, Noxa1, Cr2, Ccl19, Blnk and Fosb (Fig. 4). Tlr2, Tlr4, Map3k7, Foxp3, Nox1, Noxa1, Cr2, Ccl19, and Blnk were observed to be upregulated in the intestines of $\mathrm{DAB} / 1$ mice after $\mathrm{FB}$ ingestion, while Fosb was downregulated. There was excellent agreement between the sequencing and RTPCR data.

\section{Gene expression showed an increase in immune responses after FB ingestion}

Functional pathway enrichment identified 26 immune response pathways, which included 64 genes (Table 1 ). The main immune response pathways include 


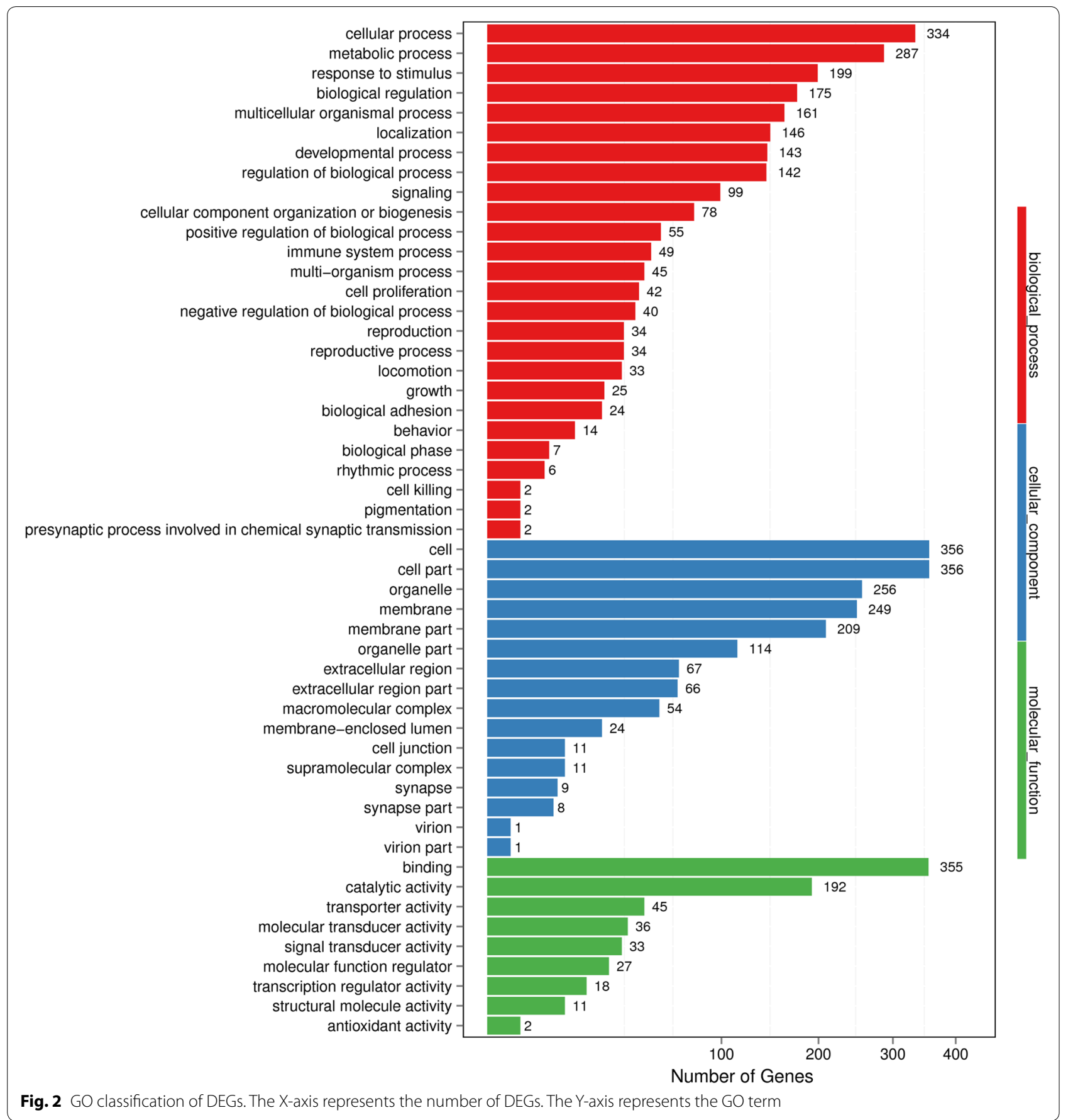

inflammatory bowel disease (IBD), leukocyte transendothelial migration, complement and coagulation cascades, the Fc epsilon Ri signalling pathway, the chemokine signalling pathway, the toll-like receptor signalling pathway, the B cell receptor signalling pathway, systemic lupus erythematosus, platelet activation, and the IL-17 signalling pathway.

\section{IgE and cytokine levels increased after FB ingestion}

Since most of the genes induced in mice treated with FB were shown to be involved in immune and inflammatory responses, we investigated plasma total IgE, histamine, IL-4 and IL-13 (Fig. 5). Marked enhancement in the levels of IgE $(3.3$-fold, $P<0.05)$ and histamine (5.1fold, $P<0.05)$ were observed in the plasma of FB-treated mice compared with the control mice. The levels of the 


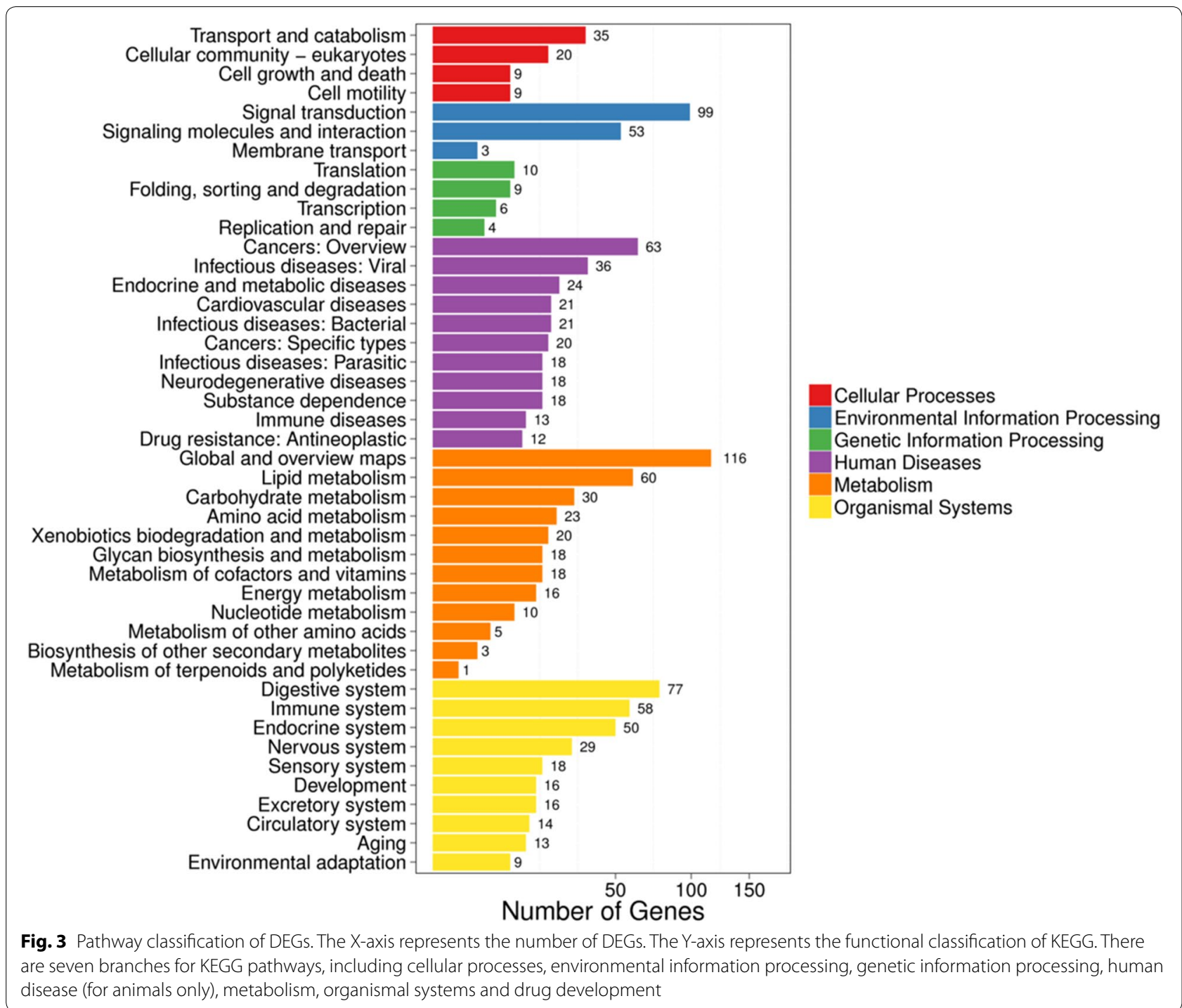

cytokines IL-4 and IL-13 significantly increased by 3.3fold $(P<0.05)$ and 2.4 -fold $(P<0.05)$, respectively, in the plasma of FB-treated mice compared with the control mice (Fig. 5).

\section{Discussion}

DBA/1 mice are used for the development of various murine models, such as halothane hepatitis and immune nephritis [26, 27]. Mostly, DBA/1 mice have been used as a model of autoimmunity [28]. The production of IgE has been shown to be significantly increased in collageninduced arthritic mice [29]. Serum IgE is considered one of the essential diagnostic parameters in the diagnostic workup of food allergy [30]. DBA/1 is a suitable mouse model for immunology and inflammation research. Therefore, we employed DBA/1 mice to investigate the FB-induced immune response.
All favism patients that have ingested FBs appear to be quite ill, with pallor, jaundice, abdominal pain, dark urine and often fever. Favism can be a very severe, lifethreatening form of acute haemolytic anaemia [3]. These symptoms are notably similar to an allergic reaction to food. Surprisingly, FB allergenicity was not reported until 2007 [16]. A 25-year-old Spanish female showed an allergic reaction after ingesting a sandwich containing FB flour [16]. Twelve percent of children with food allergies have an FB allergy [31]. Moreover, increased levels of total IgE and histamine have been observed in mice sensitized with FB [31], which are vital signs of systemic anaphylaxis [32]. In our present study, the levels of total IgE, histamine, IL-4, and IL-13 were significantly increased in the DBA/ 1 mice $8 \mathrm{~h}$ after FB ingestion, which is consistent with a report indicating that allergic patients exhibit symptoms within minutes to several hours after FB 

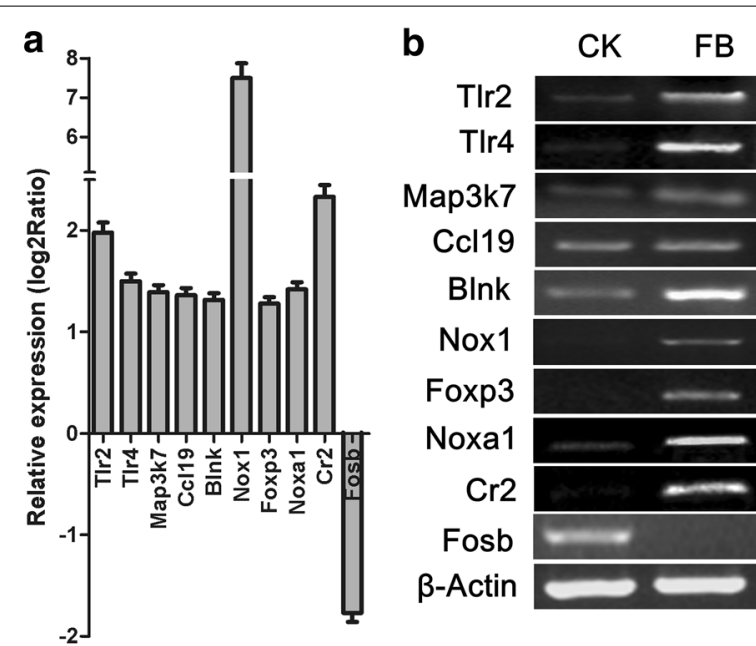

Fig. 4 Confirmation of the microarray results by RT-PCR. Gene expression of TIr-2, TIr-4, Map3k7, Ccl19, Blnk, Nox1, Foxp3, Noxa1, $\mathrm{Cr} 2$ and Fosb in mice on a control diet and mice supplemented with FBs was analysed by microarray (a) and RT-PCR (b) using the stable reference gene $\beta$-Actin. The data are presented as the mean \pm SE $(n=6)$ ingestion [33]. DBA/1 mice could serve as an alternative animal model of favism, and FBs can elicit an immune response in the DBA/ 1 mice.

In the present study, the BGISEQ-500 platform was used for sequencing and generated approximately $24.00 \mathrm{M}$ reads per sample. A total of 19,677 genes were detected. The filter composition statistics of the raw data are shown in Additional file 5: Figure S1. Clean-read quality metrics are shown in Additional file 6: Table S5. The distribution of base quality is shown in Additional file 7: Figure S2. The samples showed good quality and provided sufficient sequencing data, indicating that most transcripts were entirely covered, and reads were evenly distributed throughout the transcript. Based on the gene expression level, 769 DEGs were identified. These genes were shown to be mainly involved in the following cellular component categories: cell, cell part, organelle, extracellular region, membrane, membrane part, membrane-enclosed lumen, organelle part, macromolecular complex, cell junction, and supramolecular complex. These genes were shown to be mainly involved in the following pathways: protein digestion and absorption,

Table 1 The genes involve in immune responses pathways after FB ingestion

\begin{tabular}{|c|c|}
\hline Immune response related pathway & GenelD \\
\hline Inflammatory bowel disease (IBD) & $24088,53791,21898,20371$ \\
\hline Leukocyte transendothelial migration & $13057,226654,237038,57257,241275,16409,14677,18710,58187,216033,50490,12737$ \\
\hline Complement and coagulation cascades & $69864,78354,11537,16409,12902,14058,74145,14067,232345$ \\
\hline Fc epsilon RI signaling pathway & $57257,18710,211429,271844,102238433$ \\
\hline Chemokine signaling pathway & $18829,57257,100504362,24047,14677,11514,18710,245386,100862177,65956$ \\
\hline Toll-like receptor signaling pathway & $24088,18710,53791,21897,21898,224419$ \\
\hline Toll and Imd signaling pathway & $407243,245381,224419$ \\
\hline B cell receptor signaling pathway & $17060,57257,18710,12902$ \\
\hline Systemic lupus erythematosus & $15077,319164,319191,319167,319150,319184$ \\
\hline Platelet activation & $14677,11514,18710,211429,271844,102238433,27220$ \\
\hline IL-17 signaling pathway & $14282,70031,57890,224419$ \\
\hline Graft-versus-host disease & 110557,15051 \\
\hline NOD-like receptor signaling pathway & $13057,237038,78688,21898,100417831,381308,12374,50490,224419$ \\
\hline Allograft rejection & 110557,15051 \\
\hline Fc gamma R-mediated phagocytosis & $111002,57257,18710$ \\
\hline RIG--like receptor signaling pathway & 67664,224419 \\
\hline Natural killer cell mediated cytotoxicity & $57257,18710,379043,19368$ \\
\hline Cytosolic DNA-sensing pathway & 232934,381308 \\
\hline T cell receptor signaling pathway & $57257,18710,224419$ \\
\hline Rheumatoid arthritis & 24088,21898 \\
\hline Antigen processing and presentation & $73442,110557,15051$ \\
\hline Hematopoietic cell lineage & 16409,12902 \\
\hline Autoimmune thyroid disease & 110557,15051 \\
\hline Th1 and Th2 cell differentiation & 67701,19668 \\
\hline Primary immunodeficiency & 17060 \\
\hline Th17 cell differentiation & 381538,20371 \\
\hline
\end{tabular}




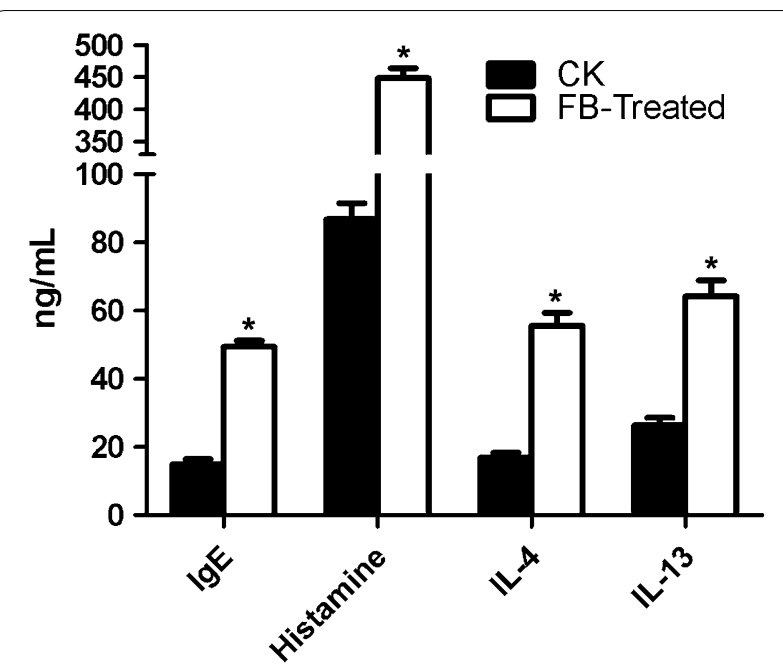

Fig. 5 The levels of IgE and cytokines in mouse blood were analysed after treatment with fava beans. The data are presented as the mean $\pm S E(n=8)$. Asterisk indicates a significant difference $(P<0.05)$ between the control and FB-treated groups

metabolic pathways, starch and sucrose metabolism, pancreatic secretion, fat digestion and absorption, arachidonic acid metabolism, carbohydrate digestion and absorption, alpha-linolenic acid metabolism, linoleic acid metabolism, metabolism of xenobiotics by cytochrome $\mathrm{P} 450$, pentose and glucuronate interconversions, glycerolipid metabolism, ether lipid metabolism, and nitrogen metabolism (Additional file 8: Table S6). Our previous study showed that ingestion of FBs could trigger alterations of protein, lipid and energy metabolism in mice [34]. The present study serves as a proof-of-concept that FBs could induce multiple alterations of lipid and amino acid metabolism after short-term FB ingestion.

In the present study, we identified 64 genes that were shown to be mostly associated with immune functions and processes, which agrees with our earlier observations that FBs induced differential alterations in the expression of genes related to Toll-like receptor 4 binding, the inflammatory response, the immune system process, and the acute-phase response in the mouse liver. The mRNA expression levels of the toll-like receptor (TLR) signalling pathway genes TLR1, TLR2, TLR4, TLR5, TAK1, and PI3K were significantly increased in FB-treated mice. The TLR1-TLR2 complex activates signalling events by regulating the PI3K/Akt signalling pathway and then activates transcription factors, such as nuclear factor kappa B (NFкB) [35, 36]. TLR4 and TLR5 promote MyD88-TRAF6TAK1 signalling to activate NF- $\mathrm{kB}$ or activator protein 1 (AP-1) $[37,38]$. These factors bind to promoter elements of genes involved in the expression of inflammatory mediators and cytokines [39], which increase the risk of developing immune-mediated diseases, such as allergic rhinitis and autoimmune diseases [40]. A previous report showed increased expression levels of TLR2 and TLR4 in patients with inflammatory bowel diseases (IBDs), which are chronic inflammatory syndromes of the gastrointestinal tract [41]. Therefore, our results suggest that FBs might induce the TLR signalling pathway to activate the mouse inflammatory response.

Furthermore, we observed that Foxp3, CCL19, CR2, and BLNK expression levels were significantly increased in FB-treated mice. Foxp3, a crucial transcription factor for regulatory $\mathrm{T}$ cell function [42], participates in regulating the inflammatory immune response and could serve as a novel target candidate for the treatment of autoimmune and allergic diseases [43]. The chemokine CCL19 is critical for allergic inflammation [44, 45]. Human CR2 plays a crucial role in linking the innate and adaptive immune responses [46, 47]. B cell linker protein (BLNK) is a central linker protein involved in B cell signal transduction and might play an essential role in the variable lymphocyte receptor B cell-mediated adaptive immune response [48, 49]. Therefore, our results indicate that FBs might induce an immune response through multiple pathways.

Furthermore, we observed that Noxa1 and Nox1 expression levels were significantly increased in FBtreated mice. Noxal acts as a central component of NADPH oxidase (NOX), while Nox1 could affect reactive oxygen species (ROS) production, both of which might contribute to oxidative stress in allergic rhinitis [50]. Thus, the increased NOX gene mRNA expression level corroborates our previous study that FBs could induce oxidative stress in mouse plasma [34].

\section{Conclusions}

In summary, we showed that immunoglobulin and cytokines were increased in FB-treated mice. The DEGs demonstrated that FBs induce multiple processes, such as the digestive system, endocrine system, environmental adaptation, and immune system. The TLR signalling pathway was observed to be affected by FB stress. Further research needs to be conducted to investigate the immune response in favism patients.

\section{Additional files}

Additional file 1: Table S1. The PCR primer sequences.

Additional file 2: Table S2. SAM analysis identified 769 differentially expressed genes of the intestine between the control and FB-treated groups. 
Additional file 3: Table S3. The differentially expressed genes implicated in each of the enriched functions.

Additional file 4: Table S4. KEGG pathway classification and functional enrichment of the DEGs.

Additional file 5: Figure S1. The filter composition statistics of raw data.

Additional file 6: Table S5. Clean-read quality metrics.

Additional file 7: Figure S2. The distribution of base quality.

Additional file 8: Table S6. 769 identified DEGs mainly involved in cellular component categories.

\section{Abbreviations}

FB: fava beans; G6PD: glucose 6-phosphate dehydrogenase; IgE: immunoglobulin E; IL: interleukin; RT-PCR: reverse transcription PCR; DAVID: database for annotation, visualization and integrated discovery; DEGs: differentially expressed genes; GO: gene ontology; IBD: inflammatory bowel disease; TLR2: toll-like receptor 2; MAP3K7: mitogen-activated protein kinase kinase kinaser; FOXP3: forkhead box protein 3; NOX1: NADPH oxidase isoforms 1; NOXA1: NADPH oxidase activator 1; CR2: complement receptor type 2; CCL19: chemokines and cytokines ligands 19; BLNK: B cell linker protein; FosB: FBJ murine osteosarcoma viral oncogene homolog B.

\section{Authors' contributions}

GD conceived of the study, and participated in its design and coordination and helped to draft the manuscript. MX participated in the design of the study. CZ carried out the RT-PCR assay. AW performed the statistical analysis. WC drafted the manuscript. All authors read and approved the final manuscript.

\section{Author details}

${ }^{1}$ Department of Biochemistry and Molecular Biology, Hainan Medical College, Haikou 571199, China. ${ }^{2}$ Biotechnology Major, Hainan Medical College, Haikou 571199, China.

\section{Acknowledgements}

The authors thank the Model Animal Research Center of Nanjing University for supplying the mice.

\section{Competing interests}

The authors declare that they have no competing interests.

\section{Availability of data and materials}

The datasets used and/or analyzed during the current study are available from the corresponding author on reasonable request.

\section{Consent for publication}

Not applicable.

\section{Ethics approval and consent to participate}

The study was approved by the Ethics Committee of Hainan Medical College for Animal Care and Use.

\section{Funding}

This study was funded by the National Natural Science Foundation of China (No. 30960171, No. 81260092) (Wangwei Cai), National Key Basic Research Program of China (2012CB526600) (Wangwei Cai) and the National Natural Science Foundation of China (No. 81641010) (Guankui Du).

\section{Publisher's Note}

Springer Nature remains neutral with regard to jurisdictional claims in published maps and institutional affiliations.

Received: 19 October 2018 Accepted: 14 February 2019 Published online: 01 March 2019

\section{References}

1. Crépon K, Marget P, Peyronnet C, Carrouée B, Arese P, Duc G. Nutritional value of faba bean (Vicia faba L.) seeds for feed and food. Field Crops Res. 2010;115(3):329-39.

2. Macarulla MT, Medina C, De Diego MA, Chavarri M, Zulet MA, Martinez JA, Noel-Suberville C, Higueret P, Portillo MP. Effects of the whole seed and a protein isolate of faba bean (Vicia faba) on the cholesterol metabolism of hypercholesterolaemic rats. Br J Nutr. 2001;85(5):607-14.

3. Luzzatto L, Arese P. Favism and glucose-6-phosphate dehydrogenase deficiency. N Engl J Med. 2018;378(1):60-71.

4. Mehta A, Mason PJ, Vulliamy TJ. Glucose-6-phosphate dehydrogenase deficiency. Best Pract Res Clin Haematol. 2000;13(1):21-38.

5. McMillan DC, Jollow DJ. Favism: divicine hemotoxicity in the rat. Toxicol Sci. 1999;51(2):310-6.

6. McMillan DC, Bolchoz $L$, Jollow DJ. Favism: effect of divicine on rat erythrocyte sulfhydryl status, hexose monophosphate shunt activity, morphology, and membrane skeletal proteins. Toxicol Sci. 2001;62(2):353-9.

7. Sartori E. On the pathogenesis of favism. J Med Genet. 1971;8(4):462-7.

8. Venter C, Pereira B, Voigt K, Grundy J, Clayton CB, Higgins B, Arshad SH, Dean T. Prevalence and cumulative incidence of food hypersensitivity in the first 3 years of life. Allergy. 2008;63(3):354-9.

9. Eigenmann PA, Sicherer SH, Borkowski TA, Cohen BA, Sampson HA. Prevalence of IgE-mediated food allergy among children with atopic dermatitis. Pediatrics. 1998;101(3):e8.

10. Boyce JA, Assa'ad A, Burks AW, Jones SM, Sampson HA, Wood RA, Plaut M, Cooper SF, Fenton MJ, Arshad SH. Guidelines for the diagnosis and management of food allergy in the United States: summary of the NIAIDsponsored expert panel report. J Am Acad Dermatol. 2011;64(1):175-92.

11. Pawankar R, Okuda M, Yssel H, Okumura K, Ra C. Nasal mast cells in perennial allergic rhinitics exhibit increased expression of the Fc epsilonRI, CD40L, IL-4, and IL-13, and can induce IgE synthesis in B cells. J Clin Investig. 1997;99(7):1492-9.

12. Aversa G, Punnonen J, Cocks BG, de Waal Malefyt R, Vega F, Zurawski S, Zurawski G, De Vries J. An interleukin 4 (IL-4) mutant protein inhibits both IL-4 or IL-13-induced human immunoglobulin G4 (IgG4) and lgE synthesis and $\mathrm{B}$ cell proliferation: support for a common component shared by IL-4 and IL-13 receptors. J Exp Med. 1993;178(6):2213-8.

13. Turner $\mathrm{H}$, Kinet J-P. Signalling through the high-affinity lgE receptor FceRl. Nature. 1999;402(6760supp):24.

14. Kinet J-P. The high-affinity IgE receptor (FcERI): from physiology to pathology. Annu Rev Immunol. 1999;17(1):931-72.

15. Okayama Y, Petit-Frere C, Kassel O, Semper A, Quint D, Tunon-deLara MJ, Bradding P, Holgate ST, Church MK. IgE-dependent expression of mRNA for IL-4 and IL-5 in human lung mast cells. J Immunol. 1995;155(4):1796-808.

16. Mur Gimeno P, Feo Brito F, Martin Iglesias A, Lombardero Vega M, Bautista Martinez P. Allergic reaction caused by a new hidden food, broad bean flour. Allergy. 2007;62(11):1340-1.

17. Damiani E, Aloia AM, Priore MG, Pastore A, Nardulli S, Lippolis C, Macchia L, Ferrannini A. Vicia faba hypersensitivity and ASA intolerance in a farmer: a case report. J Allergy (Cairo). 2011;2011:191787.

18. Bousfiha A, Aarab L. Modulation of IgE immunoreactivity to broad bean proteins after food processing in a Moroccan population. Allergol Immunopathol (Madr). 2014;42(1):29-34.

19. Tordesillas L, Berin MC, Sampson HA. Immunology of food allergy. Immunity. 2017;47(1):32-50.

20. Berin MC, Sampson HA. Mucosal immunology of food allergy. Curr Biol. 2013;23(9):R389-400.

21. Du G, Xiao M, Wei X, Zhou C, Li S, Cai W. Hepatic transcriptional profiling response to fava bean-induced oxidative stress in glucose-6-phosphate dehydrogenase-deficient mice. Gene. 2018;2018(652):66-77.

22. Kim D, Langmead B, Salzberg SL. HISAT: a fast spliced aligner with low memory requirements. Nat Methods. 2015;12(4):357-60.

23. Li B, Dewey CN. RSEM: accurate transcript quantification from RNA-Seq data with or without a reference genome. BMC Bioinform. 2011;12(1):323.

24. da Huang W, Sherman BT, Lempicki RA. Systematic and integrative analysis of large gene lists using DAVID bioinformatics resources. Nat Protoc. 2009:4(1):44-57.

25. Huang DW, Sherman BT, Tan Q, Kir J, Liu D, Bryant D, Guo Y, Stephens R, Baseler MW, Lane HC, Lempicki RA. DAVID bioinformatics resources: expanded annotation database and novel algorithms 
to better extract biology from large gene lists. Nucleic Acids Res. 2007;35(suppl_2):W169-75.

26. You $\mathrm{Q}$, Cheng L, Ju C. Generation of T cell responses targeting the reactive metabolite of halothane in mice. Toxicol Lett. 2010;194(3):79-85.

27. Hopfer $\mathrm{H}$, Hunemorder S, Treder J, Turner JE, Paust HJ, Meyer-Schwesinger C, Hopfer U, Sachs M, Peters A, Bucher-Kocaoglu B, Ahrens S, Panzer U, Mittrucker HW. Glomerulopathy induced by immunization with a peptide derived from the goodpasture antigen alpha3IV-NC1. J Immunol. 2015:194(8):3646-55.

28. Liu X, Zhou H, Huang X, Cui J, Long T, Xu Y, Liu H, Yu R, Zhao R, Luo G, Huang A, Liang JG, Liang P. A broad blockade of signaling from the IL-20 family of cytokines potently attenuates collagen-induced arthritis. $J$ Immunol. 2016;197(8):3029-37.

29. Maeda N, Yamada C, Takahashi A, Kuroki K, Maenaka K. Therapeutic application of human leukocyte antigen-G1 improves atopic dermatitis-like skin lesions in mice. Int Immunopharmacol. 2017:50:202-7.

30. Celik-Bilgili S, Mehl A, Verstege A, Staden U, Nocon M, Beyer K, Niggemann B. The predictive value of specific immunoglobulin E levels in serum for the outcome of oral food challenges. Clin Exp Allergy. 2005;35(3):268-73.

31. Kumar D, Kumar S, Verma AK, Sharma A, Tripathi A, Chaudhari BP, Kant S, Das M, Jain SK, Dwivedi PD. Hypersensitivity linked to exposure of broad bean protein(s) in allergic patients and BALB/c mice. Nutrition. 2014;30(7-8):903-14.

32. Nurmatov $U$, Dhami $S$, Arasi S, Pajno GB, Fernandez-Rivas M, Muraro A, Roberts G, Akdis C, Alvaro-Lozano M, Beyer K, Bindslev-Jensen C, Burks W, du Toit G, Ebisawa M, Eigenmann P, Knol E, Makela M, Nadeau KC, O'Mahony L, Papadopoulos N, Poulsen LK, Sackesen C, Sampson H, Santos AF, van Ree R, Timmermans F, Sheikh A. Allergen immunotherapy for IgE-mediated food allergy: a systematic review and meta-analysis. Allergy. 2017:72(8):1133-47.

33. Sampson HA, Munoz-Furlong A, Campbell RL, Adkinson NF Jr, Bock SA, Branum A, Brown SG, Camargo CA Jr, Cydulka R, Galli SJ, Gidudu J, Gruchalla RS, Harlor AD Jr, Hepner DL, Lewis LM, Lieberman PL, Metcalfe DD, O'Connor R, Muraro A, Rudman A, Schmitt C, Scherrer D, Simons FE, Thomas S, Wood JP, Decker WW. Second symposium on the definition and management of anaphylaxis: summary report-second national institute of allergy and infectious disease/food allergy and anaphylaxis network symposium. J Allergy Clin Immunol. 2006;117(2):391-7.

34. Xiao M, Du G, Zhong G, Yan D, Zeng H, Cai W. Gas chromatography/ mass spectrometry-based metabolomic profiling reveals alterations in mouse plasma and liver in response to fava beans. PLoS ONE. 2016;11(3):e0151103.

35. Jiang X, Fang L, Wu H, Mei X, He F, Ding P, Liu R. TLR2 Regulates allergic airway inflammation and autophagy through PI3K/Akt signaling pathway. Inflammation. 2017:40(4):1382-92

36. Hoesel B, Schmid JA. The complexity of NF-kappaB signaling in inflammation and cancer. Mol Cancer. 2013;12(1):86
37. Brubaker SW, Bonham KS, Zanoni I, Kagan JC. Innate immune pattern recognition: a cell biological perspective. Annu Rev Immunol. 2015;33:257-90.

38. Wi SM, Moon G, Kim J, Kim ST, Shim JH, Chun E, Lee KY. TAK1-ECSIT-TRAF6 complex plays a key role in the TLR4 signal to activate NF-kappaB. J Biol Chem. 2014;289(51):35205-14.

39. Vogel SN, Fitzgerald KA, Fenton MJ. TLRs: differential adapter utilization by toll-like receptors mediates TLR-specific patterns of gene expression. Mol Interv. 2003:3(8):466-77.

40. Corr SC, O'Neill LA. Genetic variation in Toll-like receptor signalling and the risk of inflammatory and immune diseases. J Innate Immun. 2009;1(4):350-7.

41. Szebeni B, Veres G, Dezsofi A, Rusai K, Vannay A, Mraz M, Majorova E, Arato A. Increased expression of Toll-like receptor (TLR) 2 and TLR4 in the colonic mucosa of children with inflammatory bowel disease. Clin Exp Immunol. 2008;151(1):34-41.

42. Deng G, Xiao Y, Zhou Z, Nagai Y, Zhang H, Li B, Greene MI. Molecular and biological role of the FOXP3N-terminal domain in immune regulation by T regulatory/suppressor cells. Exp Mol Pathol. 2012;93(3):334-8.

43. Choi JM, Shin JH, Sohn MH, Harding MJ, Park JH, Tobiasova Z, Kim DY, Maher SE, Chae WJ, Park SH, Lee CG, Lee SK, Bothwell AL. Cell-permeable Foxp3 protein alleviates autoimmune disease associated with inflammatory bowel disease and allergic airway inflammation. Proc Natl Acad Sci USA. 2010;107(43):18575-80.

44. Yamashita N, Tashimo H, Matsuo Y, Ishida H, Yoshiura K, Sato K, Yamashita $\mathrm{N}$, Kakiuchi T, Ohta K. Role of CCL21 and CCL19 in allergic inflammation in the ovalbumin-specific murine asthmatic model. J Allergy Clin Immunol. 2006;117(5):1040-6

45. Ploix C, Zuberi Rl, Liu FT, Carson MJ, Lo DD. Induction and effector phase of allergic lung inflammation is independent of CCL21/CCL19 and LTbeta. Int J Med Sci. 2009:6(2):85-92.

46. Hannan JP. The structure-function relationships of complement receptor type 2 (CR2; CD21). Curr Protein Pept Sci. 2016;17(5):463-87.

47. Erdei A, Isaak A, Torok K, Sandor N, Kremlitzka M, Prechl J, Bajtay Z. Expression and role of CR1 and CR2 on B and T lymphocytes under physiological and autoimmune conditions. Mol Immunol. 2009;46(14):2767-73.

48. Han Y, Liu X, Shi B, Xiao R, Gou M, Wang H, Li Q. Identification and characterisation of the immune response properties of Lampetra japonica BLNK. Sci Rep. 2016;6:25308

49. Minegishi Y, Rohrer J, Coustan-Smith E, Lederman HM, Pappu R, Campana D, Chan AC, Conley ME. An essential role for BLNK in human B cell development. Science. 1999:286(5446):1954-7.

50. Moon JH, Kim TH, Lee HM, Lee SH, Choe W, Kim HK, Lee JH, Oh KH, Lee $\mathrm{SH}$. Overexpression of the superoxide anion and NADPH oxidase isoforms 1 and 4 (NOX1 and NOX4) in allergic nasal mucosa. Am J Rhinol Allergy. 2009:23(4):370-6.

\footnotetext{
Ready to submit your research? Choose BMC and benefit from:

- fast, convenient online submission

- thorough peer review by experienced researchers in your field

- rapid publication on acceptance

- support for research data, including large and complex data types

- gold Open Access which fosters wider collaboration and increased citations

- maximum visibility for your research: over 100M website views per year
}

At BMC, research is always in progress.

Learn more biomedcentral.com/submissions 